Article

\title{
Pathways to Leadership within and beyond Cambodian Civil Society: Elite Status and Boundary-Crossing
}

\author{
Astrid Norén-Nilsson ${ }^{1, *}$ and Netra Eng ${ }^{2}$ \\ ${ }^{1}$ Centre for East and South-East Asian Studies, Lund University, 22100 Lund, Sweden; \\ E-Mail: astrid.noren-nilsson@ace.lu.se \\ ${ }^{2}$ Cambodia Development Resource Institute, 12152 Phnom Penh, Cambodia; E-Mail: netra@cdri.org.kh \\ * Corresponding author
}

Submitted: 15 March 2020 | Accepted: 10 June 2020 | Published: 4 September 2020

\begin{abstract}
Elitisation in Cambodian civil society and how such processes relate to holding elite status in the state, electoral politics, and economic fields, is poorly understood. This article seeks to identify different pathways to becoming an elite within and beyond Cambodian civil society. We focus on four case studies, representing different forms of organisations within the sectors of agriculture and youth. Three main questions are explored. Firstly, we identify different forms of capital needed to reach elite status in civil society. Secondly, we explore how elite status within civil society is related to elite status within other fields, by identifying three pathways of boundary-crossing (Lewis, 2008a) from civil society into the state, electoral politics, and economic fields. Thirdly, we map the perceived possibilities and limitations of each field. In exploring these questions, this article argues for a reappraisal of Cambodian civil society, shifting attention to the networks and platforms that fall outside of the dominant focus on professional NGOs. By empirically tracing how elites move between fields, it aspires to provide a better understanding of the contours of, and relations between, civil society and other fields (including government, electoral politics, and business), including in terms of what particular forms of power pertain to each.
\end{abstract}

\section{Keywords}

boundary-crossing; Cambodia; civil society; elites; leadership

\section{Issue}

This article is part of the issue "Civil Society Elites" edited by Håkan Johansson (Lund University, Sweden) and Anders Uhlin (Lund University, Sweden).

(C) 2020 by the authors; licensee Cogitatio (Lisbon, Portugal). This article is licensed under a Creative Commons Attribution 4.0 International License (CC BY).

\section{Introduction}

In academic accounts, Cambodian civil society is often treated as a relatively self-contained field, locked in an uneasy relationship with an authoritarian state. Though civil society is understood to be diverse, less formal groups are poorly understood and under-researched (Coventry, 2016). Elitisation within civil society has consequently been studied in terms of NGOs' accountability (Dosch, 2012) and their difficulty in establishing grassroots links (Khlok, Phoumim, \& Vanna, 2003; Malena \& Chhim, 2009). This leaves out important patterns of elite formation within and beyond Cambodian civil society today. Whilst it is well-recognised that civil society is marked by power dynamics (Mosse, 2005), the development of civil society elites remains relatively unexplored in academic literature. Processes of elite formation in civil society display interconnections and sometimes interdependence with other fields, as well as instances of boundary-crossing between them. In this article, we set out to identify different pathways to leadership within and beyond Cambodian civil society. What are some of the different pathways to elite status in Cambodian civil society? How is elite status within civil society related to elite status within other fields? What range of possibilities are afforded through civil society activity, which sets it apart from activity in other fields? 
There is a growing realisation in the literature on Southeast Asia that civil society activists may choose between different arenas for engagement. Jayasuriya and Rodan (2007) hold that in Southeast Asian hybrid regimes, state-sponsored modes of participation (in which participants exert political influence over public policy, through e.g., community consultation over policymaking or nominated members of parliament) form a continuum with civil society expression (collective actions in spaces not created by state actors). In Weiss's (2017) reworking, three principal spaces are available for activists: autonomous civil society, extra-electoral state-sponsored or institutional spaces, and electoral politics. In this article, we trace processes of elite boundarycrossing towards becoming formally incorporated into the state, electoral politics, and economic fields. Our interest in elite movement between these fields reflects our observation that it is substantial. It also reflects our different approach to elites' aims and ambitions. We do not, like Weiss (2017), assume that activists primarily respond to political opportunity structures in choosing different pathways of engagement, "weighing not only relative risks and the relative degrees of access that various routes afford but also the nature of the claims that they seek to press and ongoing feedback from intended targets" (Weiss, 2017, p. 383). We keep the motivations for elite boundary-crossing open, acknowledging that this may be a goal in itself, and that other fields may be prioritised over civil society.

Our departure point is an understanding of civil society which focuses on the nature and aims of activities rather than organisational characteristics. Civil society is here understood in broad terms as a space at the nexus of formal politics, family structures, and business; as a realm of voluntaristic, generally collective and self-supporting activity, however structured, which seeks to provide or secure public and collective good, and is separate from, and in its ideal form autonomous from, the state (Weiss, 2017 , p. 377). Our approach is in line with an emerging realisation that the concept of civil society needs to be "operationalised" in Cambodia (Henke, 2011; Waibel, 2014; Wells-Dang, 2014), where a great deal of activity fitting the above description takes place outside of formal NGOs. Waibel (2014, pp. 8-9) quoting Hannah (2007, p. 94) argues that research needs a shift to "looking at who within a society/state constellation is undertaking which civil society activities and who is accomplishing which civil society objectives," and that Cambodian social actors themselves should define which state-society relationships and activities are important. Shifting our object of study to organisations, networks, and platforms which have a significant influence through civil society activities, we take actors' accounts of their relationships and activities as a starting-point, agreeing with Waibel $(2014$, p. 1) that 'tracking', as opposed to 'pinning down', civil society should be the long-term goal of academic inquiry."

Contemporary scholarship of Cambodian civil society has pointed to a relatively weak social force which counterbalances the state to promote democracy and a pro-poor reform agenda (Hughes, 2003; Un, 2004). The Cambodian People's Party (CPP) has in different incarnations dominated the Cambodian state apparatus since 1979 , using the profits from land and natural resources on the periphery to fund service provision and rural development projects across Cambodia. Studies during the 2000s concluded that Cambodian NGOs were polarised into two groups: a strident and confrontational 'advocacy' wing ineffectually protesting hot political issues such as land conflict, human rights, and natural resource governance; and quiescent service-delivery NGOs working closely with the government to fill gaps in service provision (Malena \& Chhim, 2009; Ou \& Kim, 2013).

Significant recent changes to Cambodian civil society have resulted in new dividing lines in terms of relations with the state, which bear on patterns of elite formation and boundary-crossing. During the 2000s, NGOs gradually expanded activities into rural areas, and international NGOs with expatriate staff were replaced by local NGOs with Cambodian leaders (Öjendal, 2014). Community-based organisations (CBOs) were established in rural villages, often funded by and working closely with NGOs. The expansion of $\mathrm{CBOs}$ and increased interactions between NGOs and CBOs initially started with saving groups and self-help associations in the agriculture sector among subsistence farmers. Local saving and self-help groups are welcomed by authorities, but only as long as they are not engaged in rural mobilisation on contentious issues or party politics. Emerging grassroots mobilisations in these areas are unequivocally treated with suspicion. The escalation of land conflicts and common resource enclosure has given rise to a new strategy of network-based activism (Henke, 2011; Young, 2019). This new strategy also reflects the frustration of affected communities with professional NGOs whose support for local grievances has so far been limited and tentative (Thon, Ou, Eng, \& Ly, 2009).

Demographic change has also significantly impacted the civil society landscape. The children of a post-war baby boom became eligible to vote in large numbers by the time of the 2013 national elections, in which youth were a majority of the electorate. Seeing its support significantly weakened in the election, the CPP reasoned that preserving its dominance required urgent action to reformulate the political strategy in a manner that could co-opt significant sections of young voters (Eng \& Hughes, 2017). The government has ramped up efforts to engage youth in a range of primarily social and cultural activities through state-sponsored platforms and mass organisations. Yet, there are also independent youth initiatives to create platforms to address social and political issues.

New Cambodian civil society elites are consequently emerging who are more politically engaged and enmeshed than the previous generation of expatriate NGOs, and who navigate a variety of organisational forms, including networks, mass organisations, and plat- 
forms. To understand these novel civil society dynamics, including the contours of and relations between civil society and other fields, it is necessary to investigate who emerges as civil society elites and the dynamics driving boundary-crossing between fields.

\section{Conceptualising Elites, Fields, and Capital}

Bourdieu's theory of elites continues to provide a fruitful theoretical starting point for elite studies (e.g., Korsnes, Heilbron, Hjellbrekke, Bühlmann, \& Savage, 2017). Following Bourdieu, we understand elites not in terms of formal leadership positions, but as groups and individuals who control disproportionately large amounts of different forms of capital. Positions in social space are based on the overall amount of capital agents possess, the composition of capital, and their social trajectory (Heilbron, Bühlmann, Hjellbrekke, Korsnes, \& Savage, 2017, p. 6). Bourdieu (1986, p. 243) distinguished between economic, cultural, and social capital. Economic capital refers to money and ownership, whereas cultural capital can refer to an embodied state (such as tastes and lifestyle), an objectified state (cultural goods), or an institutionalised state (e.g. educational qualifications). Social capital is "the aggregate of the actual or potential resources which are linked to possession of a durable network of more or less institutionalised relationships of mutual acquaintance and recognition" (Bourdieu, 1986, p. 248). Each member of the network is backed by its joint volume of capital (economic, cultural, or symbolic), which functions as a "credential" (Bourdieu, 1986, p. 249). Following Khan (2012, p. 365), we include two further forms of capital: political and knowledge capital. Political capital focuses on the management of "political transitions," whilst knowledge capital refers to "ideas, knowledge, and ideology" (Khan, 2012, pp. 366, 370).

Capital is mobilised by agents to stake claims and access specific positions within particular social domains, fields (Bourdieu, 1986). For Bourdieu, the concept of field reflects a historical process whereby fields of activity have been differentiated into specialised professions (Bourdieu \& Wacquant, 1992), for example, political, economic, bureaucratic, religious, medical, scientific, and artistic. They, therefore, correspond to "familiar divisions of action into self-contained realms of endeavour" (Martin, 2003). In line with this rationale, we conceptualise civil society, the state, the realm of electoral politics, and the economic field as different fields.

The fields that have crystallised are relatively autonomous spaces each with their own specific structures, which determine the specific effects of capital (Bourdieu, 1989). Each field has its own internal logic as to the "nature of the game" and is therefore analytically distinct (Martin, 2003). Yet fields are permeable, in the sense that hierarchical positions of power are replicated between fields through the conversion of capital. For Bourdieu (1986, p. 242), this refers to "forms of exchange which ensure the transubstantiation whereby the most material types of capital-those which are economic in the restricted sense-can present themselves in the immaterial form of cultural capital or social capital and vice versa." Actors seek to reproduce capital and their positions "by means of the conversions least costly in terms of conversion work and of the losses inherent in the conversion itself" (Bourdieu, 1986, p. 253).

We understand elites not only in terms of the resources they control or have access to but also in terms of how these can be converted into different forms of capital and transferred across fields, and what the exchange rates for such transfers are (Khan, 2012, p. 362) The value and transferability of resources are defined through social processes (Khan, 2012, p. 362). The state plays a part in these and may advance or hold back civil society groups by gatekeeping the pathways to become an elite in civil society and beyond.

\section{Methodology and Introduction to the Cases}

This research builds on a qualitative case study approach, in which patterns within our framework of field theory were identified from a set of heuristic case studies (George \& Bennet, 2005, p. 75). For each case study, we studied elite formation by examining recruitment and appointment procedures, including the value and conversion rates of different forms of capital in such processes. A second analytical focus was on elite interaction and elite integration between civil society elites and elites from other fields. This included the processes through which civil society leaders cross over to take up leadership in other fields, spending and gaining what capital, and at what conversion rates. Different forms of capital, as well as pathways to leadership within and beyond civil society, were identified inductively.

Fieldwork was carried out in Cambodia between September 2018 and December 2019. In-depth case studies were carried out of six organisations, four of which are discussed here. Data was collected through interviews, observations, and document analyses. About 40 semi-structured interviews were carried out with both leaders and ordinary members of the four organisations. Questions focused on the themes of elite formation and elite interaction. A number of comprehensive 'lifework history' interviews were carried out with boundarycrossers who had crossed from civil society to other fields. Following Lewis (2008b, p. 565), this is an adaptation of the life-history method by which "in order to investigate the sector boundary-crossing phenomenon, experiences of work (whether in terms of formal career, activism, volunteering) were placed at the centre of the lifehistory data to be collected." As argued by Lewis (2008b, p. 564), the life-history method can illuminate instances of boundary-crossing in and out of civil society, shedding light on "the types of relationships and forms of power that link structures and processes across the sectors" by documenting "the motivations and experiences 
of those who have crossed over," and seeking "to explore the broader meanings and implications of these movements." Life histories also illustrate how capital becomes contingent on the fields in which they are situated (Park, Rinke, \& Mawhinney, 2016). With the permission of the interviewees, interviews were recorded and transcribed. Writing up our study, we faced the dilemma of balancing a precise presentation of findings with exposing respondents' identities (Baez, 2002). As pointed out by Lancaster (2017, pp. 95, 99), notions of authority, sensitivity, and vulnerability are fluid and relational between the researcher and participant in elite interviewing, and the small sampling frames of key individuals means that they are "vulnerable" in the sense that they could be identifiable even when anonymised. Recognising that elites may in interviews be "vulnerable elites" (Smith, 2006), we have anonymised them and the four organisations, although none of the boundary-crossers interviewed requested anonymity.

An inherent problem of the life-history method is that subjective accounts are necessarily co-produced by the informant, who particularly as an elite may seek to exert control over the research process (Smith, 2006), and the researcher-author, who decides what is included or omitted in an account and how it is framed. We have sought to redeem this by constantly reflecting on such power issues throughout the research process (Lewis, 2008b, pp. 562-563). Finally, life-history data also sets limits on generalisation. We agree with Bron and West (2000, p. 159 , as cited in Lewis, 2008b, p. 560) that individual narratives "reflect and constitute the dialectics of power relations and competing truths within the wider society," and can link personal experience with patterns of institutional change if taking into account the plausibility of the evidence, triangulation with other evidence, and an understanding of the historical content (Lewis, 2008b, p. 561).

Engaging in case research, we have not sought to select cases that are directly representative of diverse populations (George \& Bennet, 2005, p. 30), but offer instead a set of in-depth case studies reflecting different types of elitisation processes. A set of interviews during an initial pilot study made it possible to draw a broad picture of the main forms of boundary-crossing in Cambodia, and then to identify specific individuals who corresponded to these (cp. Lewis, 2012, p. 161). Our case studies are drawn from the youth and agriculture sectors, which illustrate the emerging civil society dynamics outlined in the introduction. They represent different types of organisation, ranging from network-based types to discussion platforms; they also have different relations with the state; and in terms of boundary-crossing, offer intersections with the state, electoral politics, and economic fields.

Youth Discussion (YD) identifies as an informal weekly political discussion forum for young people that seeks to cultivate a democratic political culture in Cambodia. Established in 2011 by a group of four friends, the forum had had over 2500 participants by 2020, including over
400 regular attendees. YD has attracted much media attention, which has propelled key members into civil society elite status and made them interlocutors for their generation among international media, international organisations, and the diplomatic community. Whilst it is independent, it is treated with some suspicion by the government and it suspended its activities for several months when authoritarianism hardened in September 2017.

Cambodian Ideas $(\mathrm{Cl})$ describes itself as a new social platform, presently centred around a debate and public speaking contest for Grade 12 and university students. It was founded in 2017 by six young elites in different sectors. Whilst $\mathrm{Cl}$ claims to be an independent initiative, the Union of Youth Federations of Cambodia (UYFC), which describes itself as an NGO but which functions as an unofficial youth branch of the dominant CPP, has acknowledged the $\mathrm{Cl}$ as one of its initiatives (UYFC, 2019). $\mathrm{Cl}$ is run in partnership with the Ministry of Education, Youth, and Sport (MoEYS).

Farmer Center (FC) is an organisation made up of farmers' networks, founded in 1997. By 2014, it provided direct assistance to about 160,000 families in 22 Cambodian provinces. FC focuses on agricultural innovation knowledge sharing with local farmers, farmer associations, and young entrepreneurs. Founders and grassroots have formed the backbone of a political party, founded in 2015.

Cambodian Rice (CR) is one of Cambodia's largest rice exporting companies, founded in 2011 by a former NGO leader. Operating as a successful social enterprise with 10000 farmers registered under a contract farming scheme, the entrepreneur works extensively with farmer associations.

\section{Pathways to Elite Status in Cambodian Civil Society}

In this section, we identify the different forms of capital needed to reach elite status, as well as the role that interactions with and engagement in other fields has in acquiring such status.

\subsection{Youth Discussion}

Centred on a weekly discussion forum, YD counts as its members those who are involved on a weekly basis. Membership is open to anyone. The leadership structure is made up of four generations of core members, but this arrangement is not well known, even among members. The core membership has expanded only gradually and slowly. The first generation counts the four cofounders, who started YD in 2011; the second generation 16 core members, recruited around 2014; a thirdgeneration four core members, recruited in 2018; and a fourth-generation also four core members, announced in 2020. Recruitment to core membership is informal, and generally by consensus rather than election.

Core members identified three main selection criteria, corresponding to different forms of capital, for ap- 
pointment. First among these is social capital in the form of trust. Whilst YD is non-partisan, and its core members and participants represent different political lines, the government has viewed YD with suspicion. The consequent fear of recruiting a core member who might seek to break up YD from inside has led to some hesitation to take on new core members. This dilemma also precludes there being a formal core member recruitment process. Three out of four first-generation core members have attended the Royal University of Phnom Penh's Department of Media and Communication (DMC), and they recruited like-minded people whom they were acquainted with having shared the same social networks. Consequently, the second generation leadership included several journalists and a blogger, and in the third generation, three out of four core members have a DMC connection. Personal acquaintance prior to joining the YD forum is not a criterion: several second and thirdgeneration core members benefitted from trust due to belonging to similar social circles only. The second form of capital is knowledge capital, in the form of political interest. According to co-founder Sophal, he verifies that potential core members take an interest in politics and political issues, stating that "any background is fine as long as you are interested in politics." Similarly, other core members charged that core members must share an interest in political engagement as this is necessary for organising and participating in the forum. A third criterion identified by core members is activity/engagement, which can be understood as a form of knowledge capital. For example, one core member, who was not acquainted with any other core member before attending the forum, was asked to become a core member, which she believes was because she had been vocal in forums with high profile commentators.

One co-founder, Sophal, has emerged as a key civil society actor, drawing primarily on knowledge capital which then allowed him to accumulate social capital within the field. Growing up in rural Pursat, Sophal secured several scholarships which enabled him to study at three different Cambodian universities. Winning a scholarship from the Indian embassy, Sophal went on to study political science in India where he gathered students for small group discussions about Indian local politics which triggered the idea of YD. Returning to Cambodia, Sophal made appointments at coffee shops with friends to debate politics, attracting NGO sponsorship in the form of a space for discussion. Core members attribute his leading role to his activity, in the forum and on Twitter; his social capital, in terms of being well known and having many connections; his knowledge capital, in terms of skills in political analysis; his transparency; and his commitment in guiding youth on personal, academic, and forum issues.

\subsection{Cambodian Ideas}

$\mathrm{Cl}$ was founded in 2017 by six young elites in different sectors including education, economics, health, and culture.
The six founding members are known as the "founders" and make up the board of $\mathrm{Cl}$. The board has delegated executive powers to an executive team, headed by the managing director and co-founder, Dara.

For the leadership level of $\mathrm{Cl}$, as with YD, social capital in the form of trust is paramount, but in contrast to $Y D$, the social networks it is drawn from penetrate the state. These networks are built through youth volunteering activities sponsored by the ruling CPP and the MoEYS. The six founders had been friends since their participation in the elite Ship for Southeast Asian and Japanese Youth programme, a youth exchange programme organised by the Cabinet Office of Japan and Southeast Asian governments, including the Cambodian government. One of the founders, Kanitha, then Director of the Administrative Department at Pannasastra University of Cambodia (PUC), invited fellow UYFC-member and former President of the Pannasastra Student Senate Dara to join in organising $\mathrm{Cl}$ because of his extensive experience in debate and public speaking. Further recruitment went through Dara, who relied on his personal networks. For the selection of the executive team, Dara selected several positions and advertised the remaining positions among his networks through groups on WhatsApp and Telegram. A technical team of nine mentors in debate and public speaking were then handpicked by him (interview with Dara). The connections that these recruitments built on were mainly forged through youth volunteering in three associations: the Cambodian Red Cross, Cambodia Scouts, and UYFC. All of these are patronised by the ruling CPP and have close links to state structures, primarily through the MoEYS. The joint capital of these networks functions as a 'credential' which constitute social capital for each member.

For the first two $\mathrm{Cl}$ seasons, 80 candidates were selected out of 180 and 989 applicants respectively. The forms of capital required for selection mirrored those of YD. Possessing social capital, in the form of the trust granted by in-group membership, was the most fundamental criterion. The program was advertised through the personal networks of the founders on Facebook, with the result that applicants were largely drawn from these. The second was knowledge capital. Applicants were examined through an exam, which counted for $80 \%$ of the assessment and focused on general knowledge of social science subjects including politics, economics, history, and culture. The third part of the assessment was an interview, focusing on commitment, confidence, manner, alongside content and analysis.

Being selected as a $\mathrm{Cl}$ contestant arguably means joining an elite which although formed within civil society is inherently looking to forge connections across fields. Contestants gain in social capital through networking opportunities with representatives from other fields: ministries, companies, and NGOs are regularly consulted during preparation for the contests. Two experts, one from the government, one from the NGO sector, alongside two technical experts act as judges; for the final, the Minister 
of Education, Youth, and Sport himself served as a judge. Many contestants interviewed see the main benefit of $\mathrm{Cl}$ as internal networking, forming a community which describes itself as a "family" in which the founders are referred to as "father" and "mother." From the perspective of the founders, the main outcome they wish to see is a close-knit community of capable youth bound by friendship to take on leading positions across the economic, civil society, and state fields. In the words of one co-founder: "Almost all my children are now spread out. They work in good companies, NGOs, and Ministries, which I am so happy about" (interview with Kanitha). The co-founders intend to create leadership across fields, tying together future political, civil society, and economic elites.

\subsection{Farmer Center}

The leadership group of FC was a product of donor projects established in the 1990s. FC was set up by a well-educated French Cambodian working for a French NGO. He came from a family with strong links to the political elite, who returned to Cambodia after the 1991 Paris Peace Accords. Since FC was founded with support from the French NGO in 1997, he served as chair of its board. A team leader for the French NGO, Som, was appointed as the first-generation leader of FC.

FC is governed by a board of directors with representation from the development sector. The leadership group of the organisation consists of core staff members who manage key divisions within the organisation. These are individuals who are tied to and were inspired to join FC by Som, a charismatic and visionary leader. Som draws on social capital in various ways to hold this status. He has a long-term vision for the agricultural sector and rural farmers in Cambodia. One is "Making the changes for the farmers to be successful in their enterprise that could make them a tycoon farmer (Sethy Srok Srae)." He has planned to set up a system to connect the urban and rural populations in Cambodia through capital investment of urban people into rural farmers' enterprises. In his own words, "the goal is to attract the rich to invest in FC projects and in agriculture so that Cambodia can improve the food production system" (interview with Som).

Som draws extensively on his knowledge capital, as one of very few Cambodians with PhD training abroad as an agronomist during the 1990s. He has therefore been highly sought after by NGOs and donors as well as government officials for advice and expertise in rural development. His personal character also contributes to his elite status. He is a highly trustworthy individual who commands respect. Senior staff at FC described him as a caring and down to earth personality, who is passionate about changes at the community level, where he spent most of his time sharing his knowledge with local farmers. This long-term presence and direct interaction with farmers and communities provide important social capital, not only to mobilise support from farmers but also to influence state actors who needed FC's manpower and rural community resources. The trust of a large number of rural farmers awards Som and FC with political capital that Som and his team used to mobilise voters for their newly established political party (see below) in local and national elections in 2017 and 2018. Som thus successfully converted knowledge capital and social capital into political capital.

\subsection{Cambodian Rice}

Deth is the co-founder and president of CR. Founded in 2008, CR has grown from a struggling family-owned milling business to Cambodia's leading producer and exporter of organic rice. Deth's business strategy depends on collaboration with local farmers and the farmer associations through civil society organisations. In order to meet rice export requirements, CR works with 10,000 farmers through contract farming, ensuring that farmers are committed to the company in exchange for guaranteed purchase, price, and technical assistance. Contract farming is not new in Cambodia: it was introduced by NGOs, international donors, and the government as a top priority. Nonetheless, the partnership rarely works due to high levels of distrust between farmers and companies and the lack of farmers' capacity to meet the contractual requirements.

Deth attributes his company's success to bringing his network of civil society organisations and international donors into play when working with government policymakers and smallholder farmers (interview with Deth). His previous work was exclusively in the civil society sector, including as secretary general of Cambodia Against Child Trafficking; Save the Children Cambodia; and project officer of the NGO Terre des Hommes. Previous civil society roles and engagement provided social capital in the form of relations to a wide range of key development actors in Cambodia. High-profile donor projects, including a United Nations Youth Millennium Development Goals project, enabled his public involvement interacting with high ranking government officials, development partners, and civil society organisations. His reputation in the civil society field also helped him build trust with rural actors, including rice farmers.

Deth's accumulation of economic capital has further improved access to government officials, reliant on private sector partnership and financial resources for policy implementation. Through this exchange, he has become quite influential in the policy circle which has, in turn, helped to garner support from his business peers, as demonstrated by his election to lead the Cambodia Rice Federation in 2019. His social, economic, and political capital have thus reinforced one another during interactions with the business and state fields.

\section{Boundary-Crossing}

There are three main pathways of boundary-crossing within our case studies. The first pathway is that of elite 
civil society actors, crossing over to the field of electoral politics by converting capital accrued in the civil society field. In the case of FC, long-time director Som crossed over to electoral politics. In 2014, during a time of political impasse and search for alternatives to Cambodia's political polarisation, he co-founded a network which united civil society leaders around the goal of promoting more democratic party politics. The New Party emerged out of the network the following year. Its top positions were occupied by civil society elites: Whilst Som became the New Party's Program Director, former NGO directors became its President and Secretary General. Ahead of the next national election in 2018, a party congress elected Som almost unanimously as the Prime Ministerial Candidate. Since the main opposition party, the Cambodia National Rescue Party (CNRP), had been dissolved the previous year, the New Party expected to mobilise votes from CNRP supporters.

In building his career in electoral politics, Som drew on the connections and trust established with FC grassroots. The very rationale of the New Party was to channel grassroots leadership from the civil society sector into political leadership positions. Consequently, also grass-roots level activists tended to be veteran civil society activists, with a very high proportion coming from FC. Field visits in 2018 showed that some local headquarters were used as de facto party headquarters, and interviews also suggested that New Party members were recruited through FC structures. In around 14 communes out of 27 where the party was active in May 2017, local leaders had previously been involved with FC. The connections formed with the grassroots thus formed the bulwark of support, which enabled Som's boundary-crossing to electoral politics.

A second pathway is for civil society elites' status to cross over to the state field. Here, actors converted social capital as the 'credential' bestowed by in-group membership in networks spanning the state, to political capital pertaining to policy-making positions. This pathway is exemplified by $\mathrm{Cl}$ co-founder Kanitha. A self-made civil society elite, from the age of 12 Kanitha had volunteered for the three main organisations patronised by the ruling CPP and to different extents sponsored by the MoEYS: the Cambodian Red Cross, the Cambodia Scouts, and the Youth Association of Cambodia, which in 2012 became the UYFC. In 2012, Kanitha was promoted from a province-level activist to the UYFC central committee. In co-founding the $\mathrm{Cl}$, Kanitha's crowning achievement in the civil society field, Kanitha mobilised the established networks she had built through state-sponsored youth volunteerism.

Another crucial resource Kanitha mobilised was her control over access to youth. Kanitha held the key position of Director of Administration for the well-known PUC in Phnom Penh, acting as a gatekeeper to the University by liaising between the PUC, the MoEYS, and the UYFC. The UYFC has been able to spread at the university level by recruiting key individuals in student representative bodies, who then initiate a UYFC presence at the university in question. Kanitha connected with Dara, former President of student association Pannasastra Student Senate (PASS), who also happened to be the brother of the head of the UYFC volunteers at the MoEYS. As the two took leading roles in creating $\mathrm{Cl}$, most PASS members, particularly the debate club, joined. Through Kanitha and Dara, the UYFC had thus established a significant presence at PUC. Kanitha was rewarded with an appointment as a full-time staff member in the UYFC.

Equally impressed by her work for $\mathrm{Cl}$, the Minister of Education, Youth, and Sport then appointed Kanitha as Director General of Youth, specifically requesting her to develop a similar program through the Ministry. According to Kanitha, many people have criticised her appointment to the highest technical-level position there is in the Ministry, which ordinarily requires decades of public sector experience. The Minister of Education, Youth, and Sport however routinely dismisses such criticism, by pointing to her experience in the civil society field. In this case, access to youth constituted a form of social capital that enabled boundary-crossing to the state and the conversion to political capital.

A third pathway is that of a civil society elite crossing the boundary into the economic field. This route is exemplified by Deth, president of CR. In 2012, Deth left the civil society field, turning his wife's family business to CR. The company grew very fast from 2013 to 2020, going from four family members with five staff to 200 staff, and increasing its profits from $\$ 6$ million to $\$ 40$ million. The success of the company was facilitated by Deth's former elite status in civil society. His social capital, in terms of connections with donors and NGOs, enabled cooperation with Deutsche Gesellschaft für Internationale Zusammenarbeit, Agence Française de Développement, and other donors which made the initiative successful. From 2013 onwards, the Ministry of Commerce supported the company, with the World Bank and International Finance Corporation following suit in 2014 . CR received a $100 \%$ grant to implement its capacity-building projects with rice farmers. Other factors also contributed to CR's success, most importantly the government's 2010 policy for exporting rice as well as the fact that Cambodia received preferential trade status from the EU under the Everything But Arms scheme from 2001 onwards.

Establishing himself as a leading figure in Cambodia's private sector, Deth mobilised his economic capital to become an oknha (tycoon), a title bestowed by royal decree to economic elites who invest specified amounts in government development schemes. The oknha title institutionalises an elite pact between the Cambodian economic elite and the CPP leadership, by which the oknha receive privileges and opportunities in their business ventures in return for financial contributions to the CPP state (Verver \& Dahles, 2015). Economic capital is thus converted into social capital in terms of mutual trust with state elites, which boosts further economic capital accumulation and bestows a certain political cap- 
ital in terms of influence on economic policy-making. Deth is regularly invited by the government to negotiation meetings with international investors, and much of his work focuses on building connections with the latter. He enjoys close relations with high ranking government officials in various powerful ministries: Commerce, Economy and Finance, and Agriculture, Forestry and Fisheries. Members of his board of directors include government advisers and high-ranking officials from these ministries and the Supreme National Economic Council, the Ministry of Water Resources and Meteorology, and the Ministry of Environment. He is also President of the Cambodia Rice Federation, which created in 2014 serves as a club of main elites in the rice export sector, and is chaired by a son of former deputy Prime Minister Sok An.

A second pattern is when civil society elites refrain from boundary-crossing. Among our case studies, this pattern was exemplified by YD, for which relations with the state and overall social relations played a role in shaping this outcome. No core member interviewed reported having established relations in government through YD; interactions with government officials were confined to when the latter were invited to speak at the forum. The state field is thus relatively impermeable to YD leaders (although one core member had become a civil servant). Even remaining as a civil society elite, co-founder Sophal has accrued significant political capital as a selfdefined "political entrepreneur." Sought after by the media for political commentary, Sophal is cherished by the diplomatic community and a frequent guest at several embassies.

Whilst the YD leadership does not aspire to cross to the state or electoral politics fields, its larger agenda is to prepare members to become future elites in electoral politics and the state. According to co-founder Sophal, the mission of the forum is to build the critical thinking, public speaking, and analytical skills of youth, so as to cultivate a democratic culture to replace an alleged political culture of infighting. That task necessarily remains within civil society confines for him, but has boundary-crossing ambitions into the electoral politics and state fields for YD participants. According to Sophal, YD is a "kind of investment" to turn politically ambitious young people into "political entrepreneurs." Although these are not yet members of political parties or government officials, "because they know they are not ready yet," it is "up to them when they think they are ready to go." In Sophal's words, "I keep telling them: 'If you want to be a politician, you need to be capable, have the financial resources, enough network, good knowledge and skills.'" Sauf financial capital, YD is designed to provide social and knowledge capital, to later be converted into political capital.

\section{The Perceived Possibilities and Limitations of Different Fields}

There was a perception among boundary-crossers that the state field offers unparalleled possibilities to effec- tuate social change. Boundary-crossing to the state field was motivated by a perception of it having a higher level of impact than the civil society field. For Kanitha, crossing to the state was prompted by a sense that policymaking was more impactful than UYFC work. This is perhaps surprising, given the increasingly prominent role of the UYFC, and indicates the continued primacy of holding government positions. Kanitha perceived that work in the state field offered the opportunity to engage in similar initiatives to those in civil society writ large. Her work as Director General of Youth has thus focused on upscaling and mainstreaming youth volunteering initiatives, including a planned national debatecontest, modelled on $\mathrm{Cl}$, to involve all Cambodian high schools. Comparing work at the MoEYS with work at PUC and for the UYFC, Kanitha stressed the greater responsibility that came with occupying a policy-making position (interview with Kanitha).

Boundary-crossing to the electoral politics field was similarly motivated by a perception that it offers greater potential to effectuate change than the civil society field, although only if crossing into the state field is the final destination of the individual. In the case of Som, his move to electoral politics was prompted by his desire to work at a national policy-making level. Working with FC, he stated, he could help only a small number of farmers, whereas winning an election to lead the government, he would be able to help farmers nationwide. Another strong reason that compelled him to cross to electoral politics was his conviction that "politics should not just be about elite competition" (interview with Som). The New Party was established to provide a platform for ordinary Cambodians such as farmers and grass-roots civil society leaders to become involved in politics, which should lead to them holding public office. He also cited the vulnerable position of his organisation as the government is suspicious of its grassroots organising, and its poor finances, as comparing unfavourably to work in government. However, his boundary-crossing experience to oppositional politics has yielded only negative results so far. New Party performed poorly in local elections 2017 and national elections 2018 , winning $0.07 \%$ and $1.11 \%$, respectively. $\mathrm{FC}$ has also suffered from the move of its founder to electoral politics, as it is treated with increasing suspicion by the government which closely monitors its activities, to the point that the network is now in a process of disintegration. This suggests that in the absence of cordial relations with the state, boundary-crossing to electoral politics is a high-risk endeavour.

Cambodia's rapidly expanding economic field has attracted both new and established civil society elites. According to Deth of CR, his decision to leave civil society was prompted by a realisation that there were more opportunities to help poor farmers in the private sector through contract farming. Deth described his effort in the private sector as "a new world which is starkly different from CSOs in that CSOs always wait for sponsors, while the private sector carries out their work independently, 
using their own capital" (interview with Deth). He now enjoys greater flexibility to implement his own vision and initiative without having to ask for permission and support from sponsors. Operating within the economic field is however not without limitations, particularly in relations with the government. He has been able to overcome initial suspicion and build trust with the state by investing in forming a long-term partnership with government institutions, both through formal project collaborations as well as through financial contributions to support government projects. The oknha system has thereby allowed him to become a state "insider."

Also the accounts of those who remain within the confines of civil society give important insights into the perceived possibilities and limitations of the civil society field. The commitment of Sophal of YD to stay within civil society is founded in a conviction that there he is best positioned to create a training ground for future boundarycrossers to move into the fields of the state and electoral politics. This orientation again points to the primacy of electoral politics and the holding of public office. It also suggests that absent the embedment in social relations which span the state, civil society is navigated as a field where different forms of capital can be accrued that can later be mobilised and converted to cross over into the state and electoral politics fields. In 2018, YD applied to the Ministry of Interior to register as an NGO, intending to produce future "political entrepreneurs." The request for registration was rejected, with the unofficial reason given that the inclusion of the word "political" in the NGO's name was inappropriate-signalling the state's rejection of the boundary-crossing ambition. Core members then jointly came up with the idea of opening their own coffee shop as a venue for forums. This preference for a form of social enterprise strategy again highlights civil society's reliance on funding as a perceived limitation. YD's current meeting space is offered by a foreign foundation on its premises, though core members unanimously reported that the foundation has never affected the running of the forum or discussions to date. Still, core members considered a coffee shop to present both an economic opportunity for members to become shareholders and a means of becoming completely independent of external funding demands.

\section{Conclusion}

Our key aim in this article is to illuminate pathways to leadership in Cambodian civil society and beyond. The patterns of elite formation and boundary-crossing that have been identified likely reflect durable trends, pointing towards the future architecture of Cambodian civil society. As foreign funding gradually declines, domestic, politically enmeshed elites will have to navigate diverse organisational forms and social relations with versatility. Yet whilst the article seeks to shine new light on contemporary civil society dynamics in Cambodia, its implications are extensive. The framework we propose for trac- ing and making sense of elitisation within and beyond civil societies can be broadly applied.

To become a Cambodian civil society elite, our study suggests the key importance of social capital. Arguably, this points to the role of networks characterised by mutual trust in a "controlled civil society," where there is a range of "authoritarian control mechanisms and restrictions on oppositional politics and associational life" (Uhlin, 2016, p. 43). Social capital is accrued not only within civil society but also through networks spanning the state, electoral politics, and economic fields.

Cambodia offers an interesting comparison from the perspective of what enables and motivates boundarycrossing in an authoritarian regime with a "controlled" civil society. In the wider region, patterns of boundarycrossing from civil society to the state have been identified in the Philippines (Lewis, 2008a) and Indonesia (Haryanto, 2020; Mietzner, 2013), in both cases following democratic openings which enabled a new role for civil society figures. Our four case studies revealed patterns of boundary-crossing from elite status in civil society to elite status in the state, electoral politics, and economic fields. Primarily social capital proved to be convertible so that the presence or absence of credentials bestowed by in-group membership in networks spanning the authoritarian state shaped patterns of boundary-crossing.

Attention to boundary-crossing gives a picture of an outward-oriented, rather than inward-looking, Cambodian civil society field. Lewis (2008b, pp. 570-574) distinguishes between two archetypes of boundarycrossers: "the role-based identity," in which a person's priority is simply to follow the job, with no long-term concept of the preferred sector, and the "sector-based identity," in which individuals are "guided primarily by a sense of belonging to, or identifying with, the third sector," but make an exploratory sojourn in the public sector. All three boundary-crossers here discussed defy this conceptualisation. Two of the boundary-crossers displayed strong preferences for the state field and one for the economic field, considering them more efficient fields of action to bring about change. Even the platform without high-level boundary-crossing was motivated by an aspiration for its members to take up roles in electoral politics and/or the state. The picture that emerges is the primacy, in some quarters of Cambodian civil society at least, of electoral politics and winning government office. Throughout these processes of elite formation and elite interaction, the state plays a key role in advancing and alternatively holding back civil society groups. It does so by gatekeeping pathways to becoming elites in civil society and beyond, by defining the value and transferability of resources.

\section{Acknowledgments}

The authors would like to thank the members of the "Civil Society Elites: New Perspectives on Civil Society in Cambodia and Indonesia" Research Group at 
Lund University, Sweden, and Gadjah Mada University, Indonesia, for valuable discussions, and Anders Uhlin as well as four anonymous reviewers for their helpful comments on an earlier draft. Remaining errors are those of the authors. This research was supported by the Swedish Research Council.

\section{Conflict of Interests}

The authors declare no conflict of interests.

\section{References}

Baez, B. (2002). Confidentiality in qualitative research: Reflections on secrets, power and agency. Qualitative Research, 2(1), 35-58.

Bourdieu, P. (1986). The forms of capital. In J. G. Richardson (Ed.), Handbook of theory and research for the sociology of education (pp. 241-258). New York, NY: Greenwood Press.

Bourdieu, P. (1989). The logic of practices. Cambridge, MA: Polity Press.

Bourdieu, P., \& Wacquant, L. J. D. (1992). Invitation to reflexive sociology. Cambridge, MA: Polity Press.

Coventry, L. (2016). Civil society in Cambodia: Challenges and contestations. In K. Brickell \& S. Springer (Eds.), The handbook of contemporary Cambodia (pp. 73-83). London: Routledge.

Dosch, J. (2012). The role of civil society in Cambodia's peace-building process. Asian Survey, 52(6), 1067-1088.

Eng, N., \& Hughes, C. (2017). Coming of age in peace, prosperity, and connectivity: Cambodia's young electorate and its impact on the ruling party's political strategies. Critical Asian Studies, 49(3), 396-410.

George, A. L., \& Bennett, A. (2005). Case studies and theory development in the social sciences. Cambridge, MA: MIT Press.

Haryanto. (2020). Boundary crossers: The transformation of civil society elites in Indonesia's post-authoritarian era. Politics and Governance, 8(3), 120-129.

Heilbron, J., Bühlmann, F., Hjellbrekke, J., Korsnes, O., \& Savage, M. (2017). Introduction. In O. Korsnes, J. Heilbron, J. Hjellbrekke, F. Bühlmann, \& M. Savage (Eds.), New directions in elite studies (pp. 1-28). London and New York, NY: Routledge.

Henke, R. (2011). NGOs, people's movements, and natural resource management. In C. Hughes \& K. Un (Eds.), Cambodia's economic transformation (pp. 288-310). Copenhagen: NIAS Press.

Hughes, C. (2003). The political economy of the Cambodian transition, 1991-2001. London: RoutledgeCurzon.

Jayasuriya, K., \& Rodan, G. (2007). Beyond hybrid regimes: More participation, less contestation in Southeast Asia. Democratization, 14(5), 773-794.

Khan, S. R. (2012). The sociology of elites. Annual Review of Sociology, 38, 361-377.
Khlok, S., Phoumim, O., \& Vanna, N. (2003). Margin to mainstream: An assessment of community based organizations in Cambodia. Washington, DC: World Bank.

Korsnes, O., Heilbron, J., Hjellbrekke, J., Bühlmann, F., \& Savage, M. (2017). New directions in elite studies. London and New York, NY: Routledge.

Lancaster, K. (2017). Confidentiality, anonymity and power relations in elite interviewing: Conducting qualitative policy research in a politicised domain. International Journal of Social Research Methodology, 20(1), 93-103.

Lewis, D. (2008a). Crossing the boundaries between 'third sector' and state: Life-work histories from the Philippines, Bangladesh and the UK. Third World Quarterly, 29(1), 125-141.

Lewis, D. (2008b). Using life histories in social policy research: The case of third sector/public sector boundary crossing. Journal of Social Policy, 37(4), 559-578.

Lewis, D. (2012). Across the little divide? Life histories of public and third sector "boundary crossers." Journal of Organizational Ethnography, 1(2), 158-177.

Malena, C., \& Chhim, K. (2009). Linking citizens and the state: An assessment of civil society contributions to good governance in Cambodia. Washington, DC: World Bank.

Martin, J. L. (2003). What is field theory? American Journal of Sociology, 109(1), 1-49.

Mietzner, M. (2013). Fighting the hellhounds: Prodemocracy activists and party politics in post-Suharto Indonesia. Journal of Contemporary Asia, 43(1), 28-50.

Mosse, D. (2005). Cultivating development: An ethnography of aid policy and practice. London: Pluto Press.

Öjendal, J. (2014). In search of a civil society, renegotiating state society relationships in Cambodia. In W. Gabi, E. Judith, \& N. F. Hart (Eds.), Southeast Asia and the civil society gaze: Scoping a contested concept in Cambodia and Vietnam (pp. 21-38). New York, NY: Routledge.

Ou, S., \& Kim, S. (2013). 20 years' strengthening of Cambodian civil society: Time for reflection (Working Paper Series No. 85). Phnom Penh: Cambodia Development Resource Institute.

Park, G., Rinke, C., \& Mawhinney, L. (2016). Exploring the interplay of cultural capital, habitus, and field in the life histories of two West African teacher candidates. Teacher Development, 20(5), 648-666.

Smith, K. E. (2006). Problematising power relations in 'elite' interviews. Geoforum, 37(4), 643-653.

Thon, V., Ou, S., Eng, N., \& Ly, T. (2009). Leadership in local politics of Cambodia: A study of leaders in three communes of three provinces (Working Paper Series No. 42). Phnom Penh: Cambodia Development Resource Institute.

Uhlin, A. (2016). Civil society and regional governance: The Asian development bank and the association of Southeast Asian nations. Lanham, MD: Lexington 
Books.

Un, K. (2004). Democratization without consolidation: The case of Cambodia, 1993-2004 (Unpublished Doctoral dissertation). Northern Illinois University, DeKalb, IL, USA.

Union of Youth Federations of Cambodia. (2019). Kechbrochom. Phnom Penh: Union of Youth Federations of Cambodia.

Verver, M., \& Dahles, H. (2015). The institutionalisation of Oknha: Cambodian entrepreneurship at the interface of business and politics. Journal of Contemporary Asia, 45(1), 48-70.

Waibel, G. (2014). Grasping discourses, researching practices: Investigating civil society in Vietnam and Cambodia. In G. Waibel, J. Ehlert, \& H. N. Feuer (Eds.),
Southeast Asia and the civil society gaze: Scoping a contested concept in Cambodia and Vietnam (pp. 23-40). London and New York, NY: Routledge.

Weiss, M. L. (2017). Resistance and resilience: Coping with/against the state. SOJOURN: Journal of Social Issues in Southeast Asia, 32(2), 374-404.

Wells-Dang, A. (2014). Civil society networks in Cambodia and Vietnam: A comparative analysis. In G. Waibel, J. Ehlert, \& H. N. Feuer (Eds.), Southeast Asia and the civil society gaze: Scoping a contested concept in Cambodia and Vietnam (pp. 61-76). London and New York, NY: Routledge.

Young, S. (2019). Social movements in Cambodia: Why they succeed or fail. Journal of International Relations and Development. Advance online publication.

\section{About the Authors}

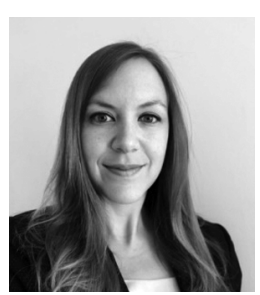

Astrid Norén-Nilsson is an Associate Senior Lecturer at the Centre for East and South-East Asian Studies, Lund University. Her scholarship looks at the contemporary politics of Cambodia, focusing in particular on democratic change, authoritarian innovation, political and civil society elites, nationalism, and notions of citizenship. She is the author of Cambodia's Second Kingdom: Nation, Imagination, and Democracy (Cornell SEAP, 2016) and has published in journals including the Journal of Southeast Asian Studies, Peace Review, Pacific Affairs, SOJOURN, and the Journal of Current Southeast Asian Affairs.

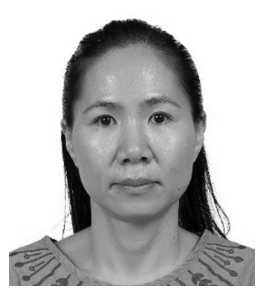

Netra Eng is Research Director at the Cambodia Development Resource Institute (CDRI) in Phnom Penh. She has been researching and writing about the political economy of institutional reforms, decentralisation, and local leadership in Cambodia. She is currently managing a number of research projects, one of which examines the impact of Cambodia's millennial generation on society and politics. 